\title{
Editorial
}

\section{Valentin Beck* \\ Introduction to the Special Issue on Normative Aspects of International Trade Institutions}

https://doi.org/10.1515/mopp-2018-0072

International trade has become an increasingly prominent and politicized topic. Just a few years ago, trade agreements such as TTIP, CETA or TPP were debated primarily by economists and other experts. Today, these and similar acronyms loom large in public discourse. ${ }^{1}$ The reasons for this shift are not too hard to detect. Trade is an age-old phenomenon, and different societies have traded with one another since the early phases of documented history. However, it is safe to say that countries have never been more economically interdependent than in modern times. In the era of economic globalization, trade has an immense impact on how benefits and burdens are created and distributed within and across societies, as well as across generations. Early optimism about the potential for global trade liberalisation to benefit everyone, including the world's poor, is now giving way to more varied and nuanced analyses. It is now more widely believed that the implementation of trade-related institutions produces winners and losers, can endanger social cohesion domestically and abroad, and can exacerbate environmental destruction and climate change. The normative evaluation of existing trade-related institutions and policies is therefore both warranted and urgent.

Three recent developments have intensified the politicization ${ }^{2}$ of the international trade regime: (1) the public controversies concerning plans for several

1 The full names of these and the below-mentioned trade agreements are: Transatlantic Trade and Investment Partnership (TTIP); Comprehensive Economic and Trade Agreement (CETA); Trans-Pacific Partnership (TPP); Comprehensive and Progressive Agreement for Trans-Pacific Partnership (CPTPP), European Union-Japan Economic Partnership Agreement (EPA); North American Free Trade Agreement (NAFTA); United States-Mexico-Canada-Agreement (USMCA). 2 See Zürn (2014) for a definition and treatment of politicization in the context of world politics.

*Corresponding author: Valentin Beck, Institute of Philosophy, Freie Universitaet Berlin, Berlin, Germany, E-mail: valentin.beck@fu-berlin.de 
mega-regional trade agreements, each covering large parts of the global economy: CETA between the EU and Canada; TTIP between the EU and the USA; and TPP between the USA and 11 other states in North and South America, South East Asia and Oceania; (2) the campaigns leading up to the US presidential Election in 2016, culminating in the election of Trump; and (3) the Brexit referendum in Britain in the same year, whose economic implications still remain highly uncertain (as of October 2018). As a result of these developments, some of the proposed deals - TPP and TTIP - were not adopted or even finalized, while others were significantly modified before their implementation, as in the case of CETA and its dispute settlement system. More recently, new trading coalitions have been formed, such as the CPTPP between the remaining 11 parties to the TPP agreement, excluding the US, and the EPA between the EU and Japan. The politicization of international trade has also shifted to older and more deeply anchored institutions. NAFTA has been renegotiated, which has led to a finalized (but not yet ratified) agreement between the US, Mexico and Canada, now renamed as USMCA. Last but not least, the governance of the World Trade Organization (WTO) is being weakened by Trump's decision to unilaterally raise tariffs on imports by several countries, most notably China, which has raised the spectre of a trade war. Newspaper editorial titles such as "How to rescue the WTO"3 are appropriate reflections of this latest development, though they would have seemed hyperbolic not too long ago. These are dramatic shifts in international trade policy. It may be too early to judge whether we are really witnessing what some observers describe as the unravelling of the postWorld War II order. But parallel developments in international environmental and economic policy, such as the US exit from the Iran nuclear deal, and its promised withdrawal from the Paris agreement on climate change, confirm that advocates of rule-based multilateralism are on the defence. The international trade regime, which had hitherto been built through comparatively slow political processes, is currently facing fundamental challenges through often rapid policy developments.

It would be simplistic to assume that these shifts are all down to the alarming rise in nationalism, embodied by Trump and, to a lesser degree, Brexit. Core features of the international trade regime have long been criticized from the other side of the political spectrum, as well, although with largely different aims in mind. Criticisms by advocates for a different kind of economic globalization - one that is more favourable to the world's poorest people and that involves greater protection of the environment - had already accompanied the Doha round of

3 https://www.economist.com/leaders/2018/07/19/how-to-rescue-the-wto (accessed on October 8, 2018) 
WTO negotiations, whose objective was to further reduce trade barriers. These negotiations stalled in the mid-2000s and have not been taken up since, as the differences between developed and developing countries regarding tariffs and agricultural subsidies remained irreconcilable. As a result, bilateral and multilateral trade agreements are on the rise, as they provide an alternative venue for countries to further their trade goals. Since then, critics have turned to bilateral and multilateral agreements designed to advance trade liberalisation within these more restricted, but still economically extensive zones.

Next to their concerns about unaddressed global threats to the environment and negative distributive effects on the poorest nations and individuals, the more progressive critics of TTIP, TPP and CETA have mostly focussed on the excessive political influence given to corporations and their agents - before and after the anticipated implementation of these trade agreements. They have criticized the secretive and non-transparent nature of the negotiations. They have also alluded to related, but more general phenomena, including: the increased corporate influence on political decision-making in the US in the aftermath of the US supreme court decision on 'Citizens United' in 2010; the notorious 'revolving door' between the business and political sector on both sides of the Atlantic; the number of lobbyists in Brussels; and privately financed 'expert studies' on the supposed social benefits of mega-regional trade agreements. When it comes to the problematic procedural aspects of trade agreements after their implementation, investor-state-dispute-settlement (ISDS) mechanisms have been a focal point. These legal instruments, which are already in force in about 3,000 mostly lesser-known and predominantly bilateral agreements, have raised the worry that they will decrease democratic legitimacy by curtailing the regulatory competence of parliaments. It was anticipated that the ISDS mechanisms in mega-regional trade agreements would weaken regulatory standards across the board, including those concerning the protection of consumers and workers, public health, privacy, the climate, and the environment more generally. Regarding TTIP and TPP, although they may never enter into force without undergoing a rebranding process, they have attracted a range of important criticisms in the public debate surrounding them. They pertain to core aspects of the present trade regime and therefore extend to other trade and investment protection agreements - whether ratified, planned or potential.

Two broad normative concerns lie at the heart of these controversies. The first is about how international trade institutions can be made to better conform with the demands of distributive justice within and across societies, referring to benefits and burdens in economic, social and environmental terms. The second involves the question of how to make international trade institutions, as well as the negotiations and public debates about them, compatible with demands of 
democratic legitimacy. The public debate on international trade can benefit from taking into account empirically informed, yet systematically normative perspectives on these matters. In other words, the expertise of normative theorists is needed when addressing the fairness and democratic legitimacy of international trade institutions, as they can provide valuable conceptual and normative insights.

The philosophical debate on trade justice is still in a comparatively early stage. ${ }^{4}$ Two interrelated levels of this debate can be distinguished. On a first level, there are methodological and normative questions about the fundamental justificatory frameworks for principles of trade justice, and their relation to general norms of distributive justice. Furthermore, there are questions concerning the substantive content of principles of trade justice, with which both domestic and international institutions and economic agents should ideally comply. Aaron James's widely discussed egalitarian theory of fairness in trade is a good example of this first level of theorizing, although his account is not restricted to it (James 2012). On a second, more concrete level lie the evaluation of our existing trade institutions and the behaviour of economic agents, and questions about how to achieve more fairness under non-ideal conditions, taking into account significant non-compliance by many relevant agents. The contemporary philosophical debate has so far yielded a number of important contributions to both levels of analysis. ${ }^{5}$ However, more work is needed.

This special issue answers this challenge. It features five contributions by philosophers and political theorists who seek to build on and advance the contemporary debate on normative aspects of international trade institutions. The emphasis of these contributions is on the second level of theorizing: they focus on the normative evaluation of existing trade institutions, such as the WTO and various mega-regional trade deals, which have so far received comparatively little attention by normative theorists. ${ }^{6}$ Next to justice-related

4 Compare a similar observation by David Miller in his introduction to an earlier symposium on 'Fair Trade', also published in this journal (Miller 2014, p. 171). For an overview of the contemporary debate, see (Barry and Wisor 2015).

5 See e. g. Barry and Reddy (2008); James (2012); the contributions in the above-mentioned symposium (see fn. 4), including those by James (2014), Risse and Wollner (2014), Walton (2014) and Brandi (2014); de Bres (2016); Miller (2017); Armstrong (2017).

6 Notable exceptions are the contributions in two recently published journal issues dedicated to mega-regional trade agreements, which appeared in Global Justice: Theory, Practice, Rhetoric (see Risse 2017, Brandi 2017, Dietsch 2017, and Banai 2017) and in MenschenRechtsMagazin (see the contributions in German by Herzog 2016, Neuhäuser 2016, Goldmann 2016, and the introduction by myself: Beck 2016). 
considerations, some contributions to this issue also deal with the problem of the democratic (il)legitimacy of international trade institutions.

In the first contribution, Christian Neuhäuser defends a realist approach to trade justice, which he distinguishes from both ideal-theoretical and transitional approaches. While the ideal-theoretical approaches defend principles of trade justice for settings where there exists a high degree of norm-compliance, transitional approaches theorize ways to improve our existing institutions in accordance with certain normative guidelines. A realist approach takes into account a specific type of political obstacle to the creation of fair(er) trade institutions, namely obstacles originating in the prevalence of self-interested agency. Neuhäuser disagrees that rational behaviour is to be conceived of as purely self-interested, as some neo-realists would see it. Instead, he proposes that theorists should work with weakly realist assumptions that reconcile self-interested agency with moral norm-compliance. Furthermore, realism about trade justice should not be understood as an alternative or rival to ideal-theoretical and transitional perspectives, but as a complementary approach that helps to determine possibilities for making trade-related institutions more just. In order to make his argument, Neuhäuser discusses a wide array of contemporary and classical approaches, both within the tradition of political realism and from the contemporary debate on trade justice, with a particular focus on Leif Wenar's proposal on how to fight the so-called resource curse. ${ }^{7}$

In the second contribution, Tadhg Ó Laoghaire assesses the WTO from a neo-republican perspective. He argues that the WTO currently allows the domination of weaker states by more powerful ones within its institutional framework. Ó Laoghaire works with a neo-republican understanding of domination, inspired by the writings of Pettit and Lovett, and applies it to the WTO negotiation forum. He lays out how this organization enables domination, despite characteristics such as sovereign equality and negative consensus decisionmaking, which could be taken as contrary evidence. Negative consensus receives a particularly detailed evaluation, as the author argues that it does not translate into effective control over decision-making procedures on the side of weaker states. This is because the more powerful states are able to 'negotiate from a position of want, against those in a position of need' (pp. 242f.). Weaker states may accept unfair bargains, as long as these promise relative improvement. And weaker states cannot afford to neglect or exit the WTO entirely, as US president Trump threatened to do as recently as August 2018.

In the third contribution, Johannes Kniess takes a critical perspective on investor-state-dispute-settlement (ISDS) mechanisms, which are a central, but

7 See Wenar (2008), Wenar (2016), and Wenar et al. (2018). 
still undertheorized element of the current global investment regime. ${ }^{8}$ His argument against ISDS consists of two steps. First, he demonstrates why ISDS protections are not justified from the perspective of distributive justice, as global investors are currently the major beneficiaries of this practice, to the detriment of developing countries and socially disadvantaged groups within them. Second, he deals with the possible objection that ISDS mechanisms are justified as institutional safeguards of morally fundamental investor rights. It is controversial whether investors do have such rights. However, Kniess shows that, even if one granted their existence, this would still not speak in favour of the current investment protection regime. The author engages with different philosophical conceptions of property rights. He concludes that moral investor rights to property can at best be understood to warrant protections from arbitrary treatment in law, but not from any regulation that would decrease the value of the property in question. This conclusion is directly applicable to ISDS, and in turn to trade deals such as CETA, which still includes an ISDS mechanism despite the fact that the EU member states and Canada already offer legal systems with arguably reliable investment protections. However, the justification of ISDS is also found wanting in less stable legal environments, according to Kniess.

The common feature of the first three contributions to this special issue is that they take a theoretical perspective on a range of normative demands related to rights and justice in international trade. In contrast, the final two contributions deal with trade-related demands of democratic accountability and legitimacy. In the fourth contribution, Lisa Herzog examines the demands of democratic accountability and contestation within trade negotiations, from an epistemic perspective. Herzog shows how the embeddedness of markets is always contested, by distinguishing what it means for markets to be factually embedded in institutional frameworks, as opposed to being normatively embedded. She then spells out how the epistemic conditions of market exchanges can be made more or less transparent, first on the level of the content of traded goods, and second on the level of the political processes that determine the rules for market exchanges. On this second level, there can be epistemic injustices when 'some voices are systematically neglected, while others are amplified' (p. 269). Herzog then details the implications of these considerations for the normative evaluation of trade deals. She shows how trade institutions could be an instrument for embedding markets in a legitimate way, by improving the epistemic conditions on the level of content and process. But she also shows how international trade deals (and the negotiations about them) have so far fallen short of these normatively warranted demands.

8 Notable exceptions are Isiksel (2016), James (2017), Dietsch (2017) and Banai (2017). 
In the fifth and final contribution to this volume, Jonathan Kuyper reflects on the politicization of trade agreements from the perspective of democratic legitimacy. He asks whether politicization automatically improves the democratic legitimacy of the corresponding negotiation processes. While some theoretical models imply that politicization is indeed a necessary step for democratization, Kuyper argues that the picture is more complex, as rule-makers are able to generate public support with invalid claims, as opposed to true, truthful and rightful claims. In the course of his argument, he clarifies a range of relevant concepts, including those of politicization, authority, and democratic legitimacy, and sets out a systematic framework for determining which forms of political mobilization and representation are in fact inhibitors, as opposed to facilitators, of democratization. In the final step, Kuyper applies this model to the TPP and TTIP negotiations. Here, the public debate about these trade deals shows how politicization can play both a positive and negative role, depending on the exact ways in with which rule-makers seek to generate public support for their positions.

Taken together, the five contributions to this special issue cast light on a broad range of normative aspects of international trade institutions. While firmly resting on normative grounds, they do not shy away from more detailed engagement with the very deficient institutions of the current international trade regime. In our worrisome era of increasing authoritarianism, we must remain wary of governments who instrumentalize the issue of international trade in order to consolidate their power by using factually false and normatively wrong assessments of trade-related institutions. Such behaviour makes it harder for truthful civil society agents to engage in constructive discourse about the kind of trade-related institutions we should collectively strive for. We should nevertheless support such honest struggles if we want to meet the steep social and environmental challenges facing us in the twenty first century.

Acknowledgements: I wish to thank the contributors and the anonymous reviewers who were involved in this special issue for their excellent work. I would also like to thank Michael Schefzcyk and Mark Peacock as the general editors of this journal for the highly constructive coordination of the review process.

\section{References}

Armstrong, C. (2017). Justice \& Natural Resources. An Egalitarian Theory (Oxford: Oxford University Press).

Banai, A. (2017). 'Is Investor-State Arbitration Unfair? A Freedom-Based Perspective', Global Justice: Theory Practice Rhetoric 10 (1): 57-78. 
Barry, C. and Reddy, S. (2008). International Trade and Labor Standards: A Proposal for Linkage (New York: Columbia University Press)

Barry, C. and Wisor, S. (2015). 'International Trade', in D. Moellendorf and H. Widdows (eds.). The Routledge Handbook of Global Ethics (Abington: Routledge), pp. 216-229.

Beck, V. (2016). 'Einführung in den Themenschwerpunkt', MenschenRechtsMagazin 21 (2): 95-98.

Brandi, C. (2014). 'On the Fairness of the Multilateral Trading System', Moral Philosophy and Politics 1 (2): 227-247.

Brandi, C. (2017). 'The Trade Regime Complex and Megaregionals - An Exploration from the Perspective of International Domination', Global Justice: Theory Practice Rhetoric 10 (1): 24-42.

de Bres, H. (2016). 'Justice and International Trade', Philosophy Compass 11 (10): 570-579.

Dietsch, P. (2017). 'Growing the Pie or Slicing it Differently - On the Need to Disentangle Two Aspects of Trade Agreements', Global Justice: Theory Practice Rhetoric 10 (1): 43-56.

Goldmann, M. (2016). 'Freihandelsabkommen und Steuergerechtigkeit: Eine menschenrechtliche Perspektive', MenschenRechtsMagazin 21 (2): 115-128.

Herzog, L. (2016). 'TTIP und die Funktionsbedingungen moralisch rechtfertigbarer Märkte', MenschenRechtsMagazin 21 (2): 99-106.

Isiksel, T. (2016). 'The Rights of Man and the Rights of the Man-made: Corporations and Human Rights', Human Rights Quarterly 38 (2): 294-349.

James, A. (2012). Fairness in Practice: A Social Contract for a Global Economy (New York: Oxford University Press)

James, A. (2014). 'A Theory of Fairness in Trade', Moral Philosophy and Politics 1 (2): 177-200.

James, A. (2017). 'Investor Rights as Nonsense - Upon Stilts', in L. Herzog (ed.). Just Financial Markets? Finance in a Just Society (Oxford: Oxford University Press), pp. 205-228.

Miller, D. (2014). 'Symposium on Fair Trade: Introduction', Moral Philosophy and Politics 1 (2): 171-175.

Miller, D. (2017). 'Fair Trade: What Does It Mean and Why Does It Matter?', Journal of Moral Philosophy 14 (3): 249-269.

Neuhäuser, C. (2016). 'Ist TTIP alternativlos? Ein Problemaufriss aus sozialliberaler Perspektive’, MenschenRechtsMagazin 21 (2): 107-114.

Risse, M. (2017). 'Multilateralism and Megaregionalism from the Grounds-of-Justice Standpoint', Global Justice: Theory Practice Rhetoric 10 (1): 1-23.

Risse, M. and Wollner, G. (2014). 'Three Images of Trade: On the Place of Trade in a Theory of Global Justice', Moral Philosophy and Politics 1 (2): 201-225.

Walton, A. (2014). 'Do Moral Duties Arise From Global Trade?', Moral Philosophy and Politics 1 (2): $249-268$.

Wenar, L. (2008). 'Property Rights and the Resource Curse', Philosophy and Public Affairs 36 (1): 2-32.

Wenar, L. (2016). Blood Oil: Tyrants, Violence, and the Rules that Run the World (Oxford: Oxford University Press)

Wenar, L., Blake, M., James, A., Kutz, C., Mehdiyeva, N., and Stilz, A. (2018). Beyond Blood Oil: Philosophy, Policy, and the Future (Lanham: Rowman \& Littlefield)

Zürn, M. (2014). 'The politicization of world politics and its effects: Eight propositions', European Political Science Review 6 (1): 47-71. 